\title{
СЕМАНТИЧНЕ ПОЛЕ "КОСТЮМ" \\ В УКРАЇНСЬКІЙ ПОСТМОДЕРНІЙ ПРОЗІ: ТЕКСТОЛОГІЧНИЙ ТА ЛІНГВОКУЛЬТУРОЛОГІЧНИЙ АСПЕКТИ
}

\author{
ЛЮДМИЛА МАРЧУК \\ Кам’янець-Подільський національний університет імені Івана Огієнка, \\ Кам'янець-Подільський - Україна \\ lyudmylamarchuk60@gmail.com \\ SEMANTYCZNE POLE "STRÓJ" \\ W UKRAIŃSKIEJ PROZIE POSTMODERNISTYCZNEJ: \\ ASPEKT TEKSTOLOGICZNY I KULTUROWO-ETNOLOGICZNY \\ LUDMILA MARCZUK \\ Narodowy Uniwersytet imienia Iwana Ohijenki w Kamieńcu Podolskim, \\ Kamieniec Podolski — Ukraina
}

STRESZCZENIE. Artykuł poświęcony jest opisowi pola semantycznego "strój" na materiale ukraińskiego tekstu postmodernistycznego. Strój — to jeden ze złożonych systemów, które funkcjonują w obszarze kultury i ściśle współdziałają $\mathrm{z}$ wieloma jej elementami. To swoisty ekran, na który projektowane są wszystkie aspekty fizycznego, duchowego, socjalnego rozwoju społeczeństwa. Bezpośrednio związany z wizerunkiem człowieka, jego nastrojem, zachowaniem, stanowi klucz do kultury, element etniczny, zwany polem semantycznym.

\author{
SEMANTIC FIELD "COSTUME" \\ IN UKRAINIAN POSTMODERN PROSE: \\ TEXTUAL AND LINGUO CULTURAL ASPECTS \\ LIUDMILA MARCHUK \\ Kamianets-Podilskiy Ivan Ohiyenko National University, \\ Kamianets-Podilskiy — Ukraine
}

ABSTRACT. The article is devoted to the description of the semantic field "costume" on the material of Ukrainian postmodern text. The costume - is one of the complex systems that functions in the area of culture and closely cooperates with a lot of its elements, it is a screen on which we can see all aspects of the physical, spiritual, social development in projection, it is directly linked to the image of a person, his mood, behavior, it is a key to culture, a component of ethnic, called the semantic field.

$\Pi$

оняття “функціонально-семантичне поле” кваліфікуємо як групування граматичних і лексичних одиниць, що опираються на певну семантичну категорію, а також різнорівневих засобів мови, які взаємодіють на грунті спільної семантики. Семантична основа відображає елементи універсального мисленнєвого змісту, що визначається позамовноюдійсністю таіїв відображенням у свідомості людей. Отже, функціонально-семантичне поле передбачає єдність плану змісту і плану вираження. 
Розрізняючи функціоналізм як методологію і як методику, О. Селіванова номінує дослідження будь-яких функціональних аспектів функціональним напрямком ${ }^{1}$.

Мовленнєвий акт — це добір засобів, що відповідають загальній смисловій спрямованості висловлення, яке формується. „Семантическое поле языка образуется большим количеством значений, которые имеют хотя бы один общий семантический элемент, как величина, вес, вмещаемость, высота, глубина, длина, интенсивность, количество, объем, площадь, размер, рост, сила, скорость, температура, толщина, число, ширина, ярость, а также все их семантичские другие образования вместе с другими частями речи (ср.: горячий, теплый, нагревать, охлаждать...)"2.

Поняття “поля” або польове моделювання набуло поширення в лінгвістиці. Мовознавці досліджують лексичні (Е. Косеріу), поняттєво-тематичні (С. Кацнельсон), синтаксичні (В. Порцинг, Г. Золотова, Н. Філічева), трансформаційні (С. Шаумян), граматичні (Л. Вейсгербер, Ф. Брюно, Г. Мюллер, О. Єсперсен, В. Адмоні, М. Глушман), лексико-семантичні (О. Гулига, С. Шендельс), словотворчі (О. Ревзіна), фонологічні (Б. Плоткін), морфосемантичні (П. Гиро), паратактичні (В. Порцинг) поля.

Назви одягу і взуття належать до одних із найдавніших типів номенів, тісно пов'язаних із матеріальною культурою народу, i, відповідно, є одним 3 виявів особливостей культури.

В українському мовознавстві назви одягу і взуття в основному досліджено з точки зору їхнього походження (Г. Війтів, В. Горобець, Г. Миронова, М. Худаш тощо), особливостей їхньої діалектної стратифікації (Л. Анісімова, Ф. Бабій, Н. Клименко, Н. Пашкова, Л. Пономар та ін.).

У 2006 році в Харкові захищена дисертація Г. Хмари Типи номінування одягу і взуття в сучасній украӥнській літературній мові (функціонально-стильовий aсnекm), матеріалом якої слугували словники сучасної української мови, жаргону, говірок, іншомовні словники. Окрім того, джерелом роботи стала авторська картотека, яку збирано протягом 1999 - 2005 років з україномовних періодичних видань, державних стандартів термінології, усних виступів, розмов, художніх творів тощо ${ }^{3}$.

Актуальність дослідження визначена відсутністю у вітчизняному мовознавстві спеціальних робіт, присвячених означеній темі, що свідчить про необхідність усебічного опису сутності номінування сучасного одягу і взуття, його основних принципів і способів, що є можливим тільки за умови дослідження назв одягу і взуття в різних складових національної мови як єдиного, цілісного явища, комплексного вивчення й установлення загальних закономірностей типів номінації. У сучасному українському (і не тільки українському) суспільстві частково змінилися функції та призначення одягу i взуття, відбувається "інтернаціоналізація” одягово-взуттєвої естетики й етикету. Таке пояснюємо глобалізаційними змінами у світі. Тому є нагальна потреба зафіксувати й докладно описати джерела формування, типи (способи, види) сучасного номінування одягу і взуття, виявити основні мовні тенденції в номі-

\footnotetext{
${ }^{1}$ О. О. С ел і в а н о в а, Актуальні напрямки сучасної лінгвістики (аналітичний огляд), Київ 1999 , c. 86

2 Ю. Д. Апресян, Лексическая семантика. Синонимические средства языка, Москва 1974 , c. $251-252$.

${ }^{3}$ Г. Х м ара, Типи номінування одягу і взуття в сучасній украйнській мові (функиіональностильовий аспект), автореф. дис. ... канд. філол. наук, Харків 2006, с. 5.
} 
Семантичне поле “костюм” в украӥнській постмодерній прозі: текстологічний та лінгвокультурологічний аспекти

нуванні та соціологічну функцію номена “костюм” для сучасного українця. Костюм складає частину образу людини, репрезентує іiї соціальний статус. У сучасних текстах простежуємо такі вислови: А остогидлий імідж такого собi дурнуватого стерва, хоч і корисливого, але корисного, який мусиш надягати, щоб тебе бодай якось сприймали? А ияя уніформа у вигляді міні, сережок у пупках $і$ якихось мотузочок на грудях $і$ стегнах ...? $?^{4}$, де одяг створює певний образ, указуючи на професію, риси характеру чи життєву мету людини. Одяг стає в таких випадках уніформою, порівн.: Перш за все перевіряю свою уніформу. Так, чорна міні-спідничка та яскраво-червона напівпрозора блузка не зіжмакані. Колготи новісінькі, набійки на високих закаблуках иілі - все в нормі , напр., уніформа офіціантки. Костюм указує і на соціальний статус людини: Чорний светр, дорогі черевики - Беня з останніх сил намагався виглядати пристойно, хоча я знав краще за інших, що фірму його відтиснули й жсие він за рахунок банківських вкладень, які зумів зберегти .

Семантичне поле $\epsilon$ такою системою, завдяки якій здійснюється вивчення семантичних змін у мові. Р. Мейер, напр., виділяе три типи семантичних полів: 1) природні (назви дерев, тварин, частин тіла та ін.), 2) штучні (назви військових звань, складові частини механізмів та ін.), 3) напівштучні (термінологія мисливців і рибалок, етичні поняття та ін.) ${ }^{7}$.

Семантичне поле - термін, який застосовують у лінгвістиці для опису сукупності мовних одиниць, об’єднаних спільною (інтегральною) ознакою, словами, що мають певний спільний нетревіальний компонент значення. У ролі таких одиниць спочатку розглядали одиниці лексичного рівня - слова, пізніше словосполучення та речення. Це можна простежити під час опису поля кольороназв, що має кілька колірних рядів, об'єднаних спільним семантичним компонентом "колір": червоний - рожевий - рожевуватий - малиновий; синій голубий - голубуватий - бірюзовий і т. д. Напр., образи “прихіпованої” (авт.) молоді кінця 70-х рр. XX ст. (одна ситуація, молодь одного, модного на той час, напрямку) Ганна Ручай в романі Жіночий бокс створює за допомогою таких мовних засобів опису костюму: Крім неї та цих двох пістряво вдягнених жевжиків у кафе нікого не було...; ...Грицько з зачіскою, як у героя фільмів, що демонструють у Домі кіно лише в закритому залі для елітної публіки, і в небачених рябих итанях; У нього завжди все найкраще, навіть, як він запевняє, оці темні закордонні окулярчики - вузенькі й непроникні, вони тісно прилягають до обличчя, роблять його аж якимось лиховісним; Жоден “даӥиник” не посміс зачепити ие добре вже знане у величезному місті авто - хай той "прихіпований покидьок” у мистецьки заляпаних білою фарбою штанях хоч гірлянди з дівчаток собі на дверията навішає му разі включає все, що штучно змінює вид людини, що $є$ на іiї тілі: одяг, головний убір, взуття, зачіска, доповнення (аксесуари), макіяж, пірсинг, парфуми. На всі етапи життя костюма найбільше впливає сама людина, їі тіло та душа, що і складає особливість костюма, на відміну від інших речей, тобто костюм “культурна шкіра" людини, що найближча їй у предметному світі.

\footnotetext{
${ }^{4}$ Г. Ручай, Жіночий бокс, Київ 2008, с. 5.

${ }_{5}^{5}$ Д. Корній, Т. Владми рова, Крила кольорухмар, Харків 2015, с. 22.

${ }^{6}$ С. Жадан, Месопотамія, Харків 2014, с. 17.

${ }^{7}$ Р. Мей ер, Обзоры. Теория семантических полей, [в:] „Вопросы языкознания”, Москва 1971, № 5, с. 105-113.

${ }^{8}$ Г. Ручай, зазнач. джер., с. $47-55$.
} 
Одним 3 найактуальніших питань лексичної семантики О. Антомонов уважає трактування структури лексико-семантичного поля (ЛСП). Чинником, що об’єднує погляди дослідників, він називає розуміння ЛСП як структури, що має ядро і периферію9.

Щодо різноманітних груп лексики, то відзначимо досить довільне використання терміна “поле” в мовознавстві. Проте всі ці відмінності об'єднані думкою, що ЛСП - це спосіб відображення системної організації словника.

У сучасній лінгвістиці ЛСП - це семантико-парадигматичне утворення, що має певну автономність і специфічні ознаки організації: спільну нетривіальну частину в тлумаченні, ядерно-периферійну структуру, існування зон семантичного переходу ${ }^{10}$.

Семантичне поле може мати такі основні властивості: воно інтуїтивно зрозуміле носієві мови; автономне, є самостійною підсистемою мови; одиниці семантичного поля пов'язані системними семантичними зв'язками; кожне семантичне поле має відношення до інших семантичних полів та утворює 3 ними мовну систему.

В основі теорії семантичних полів лежить уява про існування в мові окремих семантичних груп та про можливість уходження мовних одиниць в одну чи кілька таких груп на основі різних відношень: синонімічних, антонімічних тощо.

Така уява про лексичну систему є лінгвістичною гіпотезою, а тому часто стає методом проведення мовного дослідження.

Елементи окремого семантичного поля пов'язані регулярними та системними відношеннями, а, отже, усі поля взаємнопротиставлені. Семантичні поля можуть перетинатися або повністю поглинатися один одним. Значення кожного слова найповніше визначається лише в тому разі, коли відомі значення інших слів того ж поля. Крім того, окрема лексема може мати кілька значень, тобто бути членом кількох полів. Напр.: Ногу висмикнула й із жахом дивилася, як смолисто-густа рідина засмоктує червоненький човник, який був щойно ї̈ взуттям ${ }^{l 1}$. Лексема човник із цього тексту одночасно належить до поля "взуття" (вужчого) та "костюм” у значенні “одяг” (ширшого), а термін човник до кількох полів: “судно”, “деталь верстатів”.

Семантичну ознаку, що лежить в основі семантичного поля, можна також роглядати як понятійну категорію, що співвідноситься з довкіллям та досвідом людини щодо нього. Найрозповсюдженішим різновидом семантичного поля $€$ поле парадигматичного типу, одиницями якого є лексеми однієї частини мови та такі, що мають у значенні спільну граматичну сему. Напр., у тексті Taто досі любить військову форму: для нього немає зручнішої сорочки, аніж військова, а кольору хакі надає перевагу навіть у шкарпетках та домашніх капиях. Він $i$ зараз був в офіџерських штанах з випоротими лампасами ${ }^{12}$ виділяємо колір хакі, що може входити як частина до цілого в семантичне поле "колір" і в семантичне поле "костюм".

Семантичне поле дієслів представимо об'єднанням синонімічних рядів: розмовляти - говорити - балакати - спілкуватися...; сварити - критикувати ...; дразнити - висміювати - жартувати ... тощо.

9 А. Антомонов, Исследование структурной организации лексико-семантического поля, дис. ... канд. филол. наук, Киев 1987.

${ }^{10}$ С. Ден и с о в а, Типологія категорій лексичної семантики, Київ 1996, с. 78.

${ }^{11}$ Г. Ручай, зазнач. джер., с. 56.

${ }^{12}$ Г. В до в и чен ко, Хто такий Ігор?, Київ 2010, с. 18. 
Семантичне поле "костюм” в украӥнській постмодерній прозі: текстологічний та лінгвокультурологічний аспекти

Загальна семантична ознака, що об'єднує елементи конкретного семантичного поля, в інших семантичних полях може функціонувати як диференційна. Напр.: Фарбоване волосся, на пухких пальиях зі свіжим манікюром - масивні персні. Мляві видовжені мочки вух, відтягнуті золотими кульчиками з олександритами ${ }^{13}$. Семантичне поле “костюм" включає й поняття зачіски (фарбоване волосся), і аксесуари (масивні персні, золоті кульчики з александритами) та ін. Інтегральна семантична ознака цього поля - “зовніший вигляд”, а “аксесуари”, що його створюють, - диференційна ознака.

Якщо автор, створюючи власний семантичний простір тексту, що набуває цілісного вигляду як індивідуально-авторський образ світу, прагне розуміння інтенцій, то реципієнт не лише намагається спроектувати власне сприйняття тексту на авторську картину світу, а й додати до неї елементи суб'єктивного світосприйняття, власного семантичного простору - інтерпретувати. Напр., опис костюма львівської жінки передає захоплення автора та головної героїні: Досі дивуюся тим відданим культу жіночності львівським панянкам та паням, які спацерують, ніколи не поспішаючи $і$ завжди запізнюючись, стометрівкою чи площею Ринок. Капелюшок, високі підбори, елегантне платтячко чи плащик (залежно від пори року) розміру а-ля Коко Шанель, розкішне декольте, завішене прегарними прикрасами. Чоловікам зносить дах від такої жіночності... (Дара Корній, 22) ${ }^{14}$.

Отже, зміст народжується під час поєднання семантичних просторів мовця і реципієнта, унаслідок з'являються спільні моделі й точки перетину — поняття. Семантичне поле складається з ментальних моделей, що грунтуються навколо відповідних ментальних феноменів. Це утворення є схемою текстового світу, моделлю можливого світу: цілісний зміст тексту є поєднанням авторського семантичного поля із семантичними полями всіх реципієнтів, які інтерпретують текст.

\footnotetext{
${ }^{13}$ Там само, с. 21.

${ }^{14}$ Д. Корній, Т. Владми рова, зазнач. джер., с. 20.
} 